\title{
Uterine Corpus Diffuse Leiomyomatosis
}

National Cancer Institute

\section{Source}

National Cancer Institute. Uterine Corpus Diffuse Leiomyomatosis. NCI Thesaurus. Code C40170.

An unusual condition characterized by the presence of numerous small benign smooth muscle neoplasms located throughout the body of the uterus. 